\title{
Ázerbájdžán - křižovatka na Velké hedvábné cestě
}

\author{
David Majer \\ Ostravské muzeum, př́spěvková organizace, Masarykovo nám. 1, 72841 Ostrava 1
}

Do redakce doručeno 11. května 2017; k publikaci přijato 5. června 2018

Text studie vznikl díky podpoře z projektu IGA 2016 katedry historie FF UP v Olomouci.

\section{AZERBAIJAN - CROSSROADS OF THE GREAT SILK ROAD}

\begin{abstract}
Since antiquity, Azerbaijan has been a natural crossroads of routes linking remote areas along the north-south and east-west axes. It is no exaggeration to say that historical Azerbaijan formed the border between the West (North) and the Orient. The historical events of epochs prior to the advent of the Achaemenid Empire made this country the place where trade and civilization intersected. Azerbaijan progressively became a strategic enclave of interests among the great powers, including Persia, the Roman Empire and later Byzantium, Sassanid Iran, and the emerging Russian Empire. This historical-geographical predestination of Azerbaijan was only underscored further during the High Middle Ages. Essentially two parallel routes lead from Trebizond (later Trabzon) on the Black Sea coast in this period to the Arax valley. One of them followed the part of the route described by Xenophon in his Anabasis and passed through the valley of the river Çoruh (maybe Xenophon's Harpasos?). The second of the routes led to the valley of the upper stream of the Western Euphrates (the second option for Xenophon's Harpasos?) and through today's Erzurum directly to the upper Arax. The other east-west road, heading north along the southern foothills of the Greater Caucasus, is probably a little younger with regard to its frequency of regular business contacts. Due to the intensity of traffic, probably the youngest of the three main routes that crossed the territory of historical Azerbaijan is the north-south branch of the Silk Road, running along the western coast of the Caspian Sea. Today this road remains a tangible symbol of contacts between the two different worlds of Europe and the Orient.
\end{abstract}

\section{KEY WORDS Azerbaijan; Great Silk Road; trade routes; Caucasus; Persia}

ABSTRAKT Ázerbájdžán byl od starověku přirozenou křižovatkou dálkových cest, spojujících vzdálené oblasti ve směru severo-jižním i východo-západním. O historickém Ázerbájdžánu lze bez nadsázky říci, že tvořil hranici mezi Západem (Severem) a Orientem. Roli centra obchodu a civilizačního průsečíku přisoudily této zemi již dějinné události předachaimenovských epoch. Ázerbájdžán se stal postupně strategickou enklávou zájmů řady velmocí, včetně Persie, Rímské říše, později Byzance, sásánovského Íránu a vznikajícího Ruského impéria. Období vrcholného středověku pak tuto historicko-geografickou predestinaci Ázerbájdžánu pouze podtrhlo. Z Trapezuntu (pozdějšího Trabzonu) na černomořském pobřeží vedly již v tomto období v podstatě dvě paralelní cesty k údolí Araxu. Jedna z nich kopírovala část trasy, kterou popsal ve své Anabazi Xenofón a procházela údolím řeky Çoruh (možná Xenofóntův Harpasos?). Pravděpodobně o něco mladší, pokud jde o pravidelnou frekvenci obchodních kontaktů, je druhá východo-západní komunikace, vedoucí severněji, podél jižního podhůří Velkého Kavkazu. Vzhledem k intenzitě dopravní frekvence pravděpodobně nejmladší ze tří hlavních cest, které procházely územím historického Ázerbájdžánu, je severo-jižní větev Hedvábné cesty, vedoucí podél západního pobřeží Kaspického moře. Tato cesta zůstává dodnes hmatatelným symbolem kontaktů mezi dvěma odlišnými světy Evropy a Orientu.

\section{KLÍČOVÁ SLOVA Ázerbájdžán; Velká hedvábná cesta; obchodní cesty; Kavkaz; Persie}

Ázerbájdžán byl od starověku přirozenou křižovatkou dálkových cest, spojujících vzdálené oblasti ve směru severo-jižním i východo-západním. O historickém Ázerbájdžánu ${ }^{1}$ lze

1 Do rámce tzv. historického Ázerbájdžánu lze zahrnout oblast Dagestánu s historickým centrem v Derbentu, stejně tak jako čtyři jižní ázerbájdžánské provincie v dnešním Îránu s centry v Tabrízu a Ardabílu. Specifickou kapitolou je potom oblast Karabachu, kterou je nutno vnímat jako integrální součást ázerbájdžánského území. Složitou problematiku stanovení historicko-geografických kontur historického Ázerbájdžánu však tento příspěvek z důvodu zachování kontinuity obsahu neotevírá. 


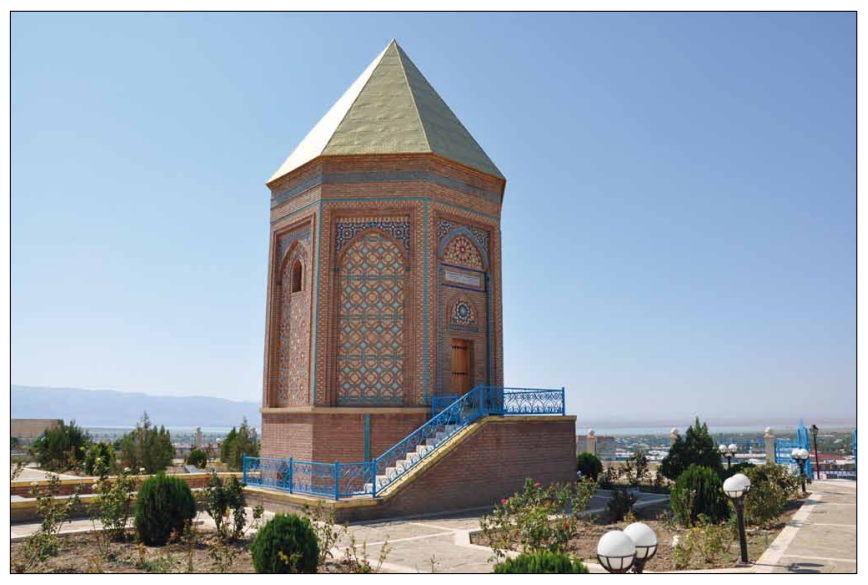

Obr. 1. Nachičevan, mauzoleum na místě hrobu, v němž byl podle tradice pohřben praotec Noe, se tyčí nad řekou Arax. Údolí Araxu, tvořící dnes hranici $\mathrm{s}$ Íránem, bylo od pravěku přirozenou osou dálkových cest v západo-východním směru. Foto: David Majer, 2011.

bez nadsázky říci, že tvořil hranici mezi Západem (Severem) a Orientem. Roli centra obchodu a civilizačního průsečíku přisoudily této zemi již dějinné události předachaimenovských epoch. Ázerbájdžán se stal postupně strategickou enklávou zájmů řady velmocí, včetně Persie, Římské říše, později Byzance, sásánovského Íránu a vznikajícího Ruského impéria. Období vrcholného středověku pak tuto historicko-geografickou predestinaci Ázerbájdžánu pouze podtrhlo.

Průběh dálkových cest ${ }^{2} \mathrm{v}$ Ázerbájdžánu určovala morfologie krajiny, stejně jako vztahy se sousedními říšemi a státy. Ázerbájdžán se stal křižovatkou dálkových cest a oblastí s důležitým tranzitním významem nejen v kontextu kaspické oblasti, popř. Jižního Kavkazu, ${ }^{3}$ nýbrž celého Předního východu a tudíž i vzhledem $\mathrm{k}$ průběhu páteřních větví Velké hedvábné cesty, jejíž podobu, tj. směr hlavních komunikačních tepen, od prvopočátku s až magnetizující silou ovlivňoval. Oním páteřním úsekem Hedvábné cesty, spojujícím Blízký východ se Střední Asií, byly trasy vedoucí jižně od Kaspického moře přibližně v linii Damašek (Antiochie) - Palmýra (Baghdád, Arbíl) - Tabríz - údolí horního Zandžánu - Rej - Mašhad a dále do nitra Asie.

V souvislosti s nejstaršími, nicméně již historickými obdobími existence dálkových cest, lze s jistotou hovořit pouze o nemnoha potencionálních střediscích obchodu, jejichž lokalizace umožní alespoň přibližně rekonstruovat průběh těchto komunikací. Byla jimi nepochybně všechna politická centra raných států, místní opevněná sídla s citadelami a strážní hrady, popřípadě kultovní a náboženská centra, $\mathrm{k}$ nimž nejstarší dálkové cesty směřovaly, resp. které byly postaveny již na základě jejich existence.

$2 \mathrm{~V}$ textu je užíváno pro stanovení průběhu komunikací častěji slovo cesta, správnější by však mělo být, zejména v souvislosti s geomorfologickými a hydrologickými ukazateli, použití obecnějšího termín trasa a v mnoha případech ještě obecnějšího pojmu směr.

3 Namísto nesprávného, nicméně již zažitého označení Zakavkazsko byl zvolen korektnější a serioznější název Jižní Kavkaz.

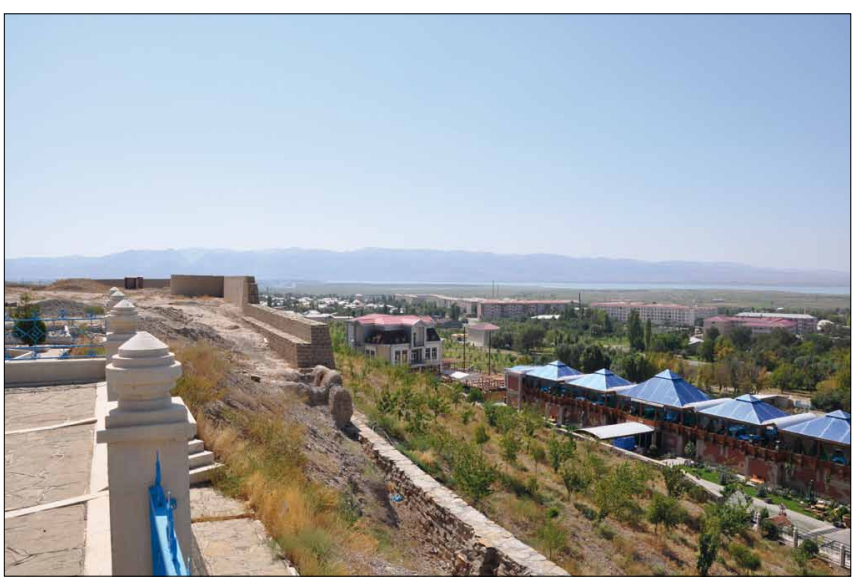

Obr. 2. Nachičevan, údolí Araxu, tvořící ázerbájdžánsko-íránskou hranici Foto: David Majer, 2011.

Samotná identifikace reliktů dávných cest $\mathrm{v}$ terénu naráží na řadu obtíží. Jedna z nich tkví v zásadní odlišnosti použitelné metodologie v porovnání s postupy neinvazivních metod archeologie využívaných u nás, ve Střední a západní Evropě. Úvozové cesty obvyklé $\mathrm{v}$ našich zemích se totiž na Předním východě (řeč bude nadále i v prípadě zobecňujících tezí především o území historického Ázerbájdžánu), pokud vưbec existovaly, velmi obtížně lokalizují. Příčina tkví zejména v odlišném způsobu dopravy na dlouhé vzdálenosti. Mnohem méně zde totiž byly používány vozy. Karavany byly odkázány nejčastěji pouze na sílu a vytrvalost soumarů. Podíl na neexistenci dlouhodobě stabilních cest v evropském slova smyslu a na změnách průběhu hlavních i lokálně významných komunikací mají také častější změny společensko-politické situace $\mathrm{v}$ těchto oblastech. Rovněž charakter krajiny je ve většině oblastí, kudy probíhaly stezky napojující se na hlavní tepny Hedvábné cesty, odlišný od středoevropských terénů. Proto se zde nesporné pozůstatky a stopy po dlouhodobém dopravním provozu nesnadno nalézají a prokazují.

Hlavní pozemní komunikace probíhaly územím Ázerbájdžánu ve starověku od severozápadu k jihovýchodu ( $v$ obou směrech) ve dvou základních liniích, které byly mezi sebou spojeny regionálně významnými cestami, vytvářejícími velmi přehlednou a logickou sít. K těmto dvěma přibližně západo-východním trasám lze později připojit třetí cestu, vedoucí podél západního pobřeží Kaspického (Chazarského) moře severo-jižním směrem po souši, po moři (plavbou podél pobřeží), popř. kombinací obou způsobů dopravy.

\section{JIHOÁZERBÁJDŽÁNSKÁ (ATROPATENSKÁ) VĚTEV HEDVÁBNÉ CESTY}

V nejstarších dobách ázerbájdžánských dějin, v období existence Asyrské ř́iše, říše Urartu, Mannejského království a dalších států, tedy přibližně od počátku 1 . tisíciletí př. n. 1., byla důležitými křižovatkami obchodních cest řada opevně- 


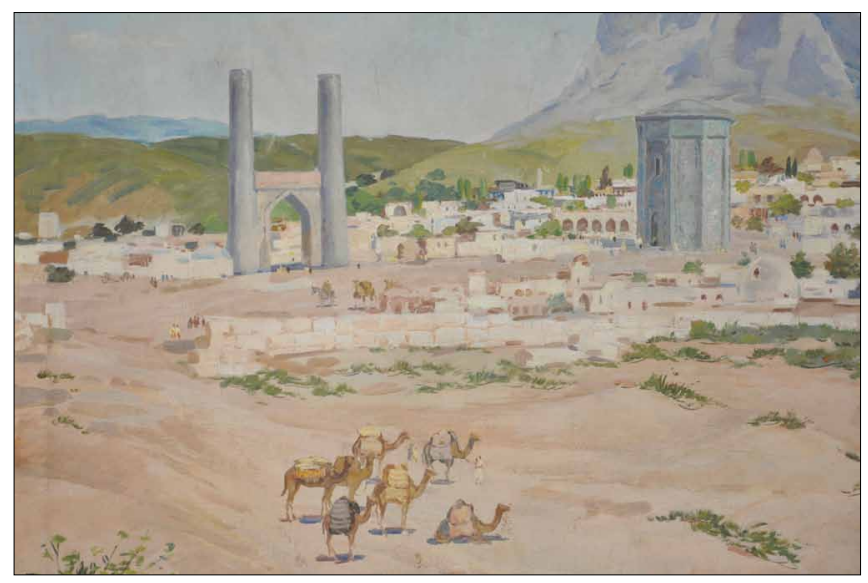

Obr. 3. Davud Kazimov, Nachičevan ve 12. století, 1976, Nachičevan, Historické muzeum. Foto: David Majer, 2011.

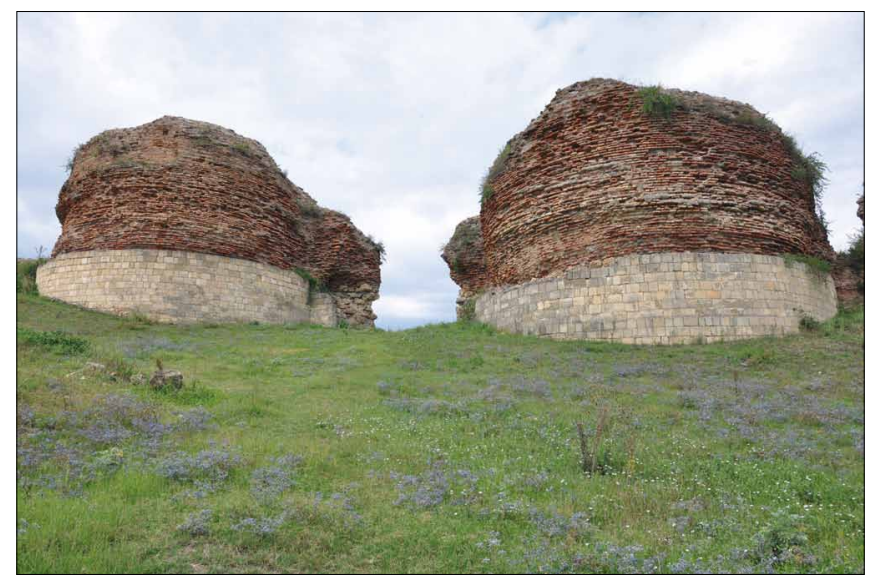

Obr. 5. Zř́ícená brána starověké Gabály, nejstaršího hlavního města kavkazské Albánie. Foto: David Majer, 2012.

ných měst $\mathrm{v}$ čele $\mathrm{s}$ hlavním městem Asýrie Ninive ( $\mathrm{v}$ dnešním Iráku). Za neméně důležitá centra lze považovat rovněž Arbíl, ${ }^{4}$ Aššur, Dúr Šarrukín („Pevnost Sargonovu“, dnešní Chorsábád), Calah a nemnoho dalších. Sem se sbíhaly cesty od přístavů $\mathrm{z}$ východního pobřeží Středozemního moře a rovněž cesty spojující černomořské př́istavy s Mezopotámií přes Pontské pohoří a Arménskou vysočinu.

Důležitá tranzitní místa Asyrské ŕíše zmiňuje okrajově řada dochovaných epigrafických památek, včetně tzv. Stély z Kurchu (853 nebo 852 př. n. l.), popisující činy krále Salmanasara III. Je zde mimo jiné líčeno, jak se král v čele armády s válečnými vozy prodírá nehostinnou krajinou horských průsmyků do Aridi, opevněného hlavního města království Ninni. Když následně město opustil, „narazil na obtižné cesty a strmé hory, kterými bylo nutno prosekat se pomocí bronzových a měděných krumpáčů a vést válečné vozy a vojsko près ně“.

4 Nováček 2008, 259-302.

5 Luckenbill 1926, 213.

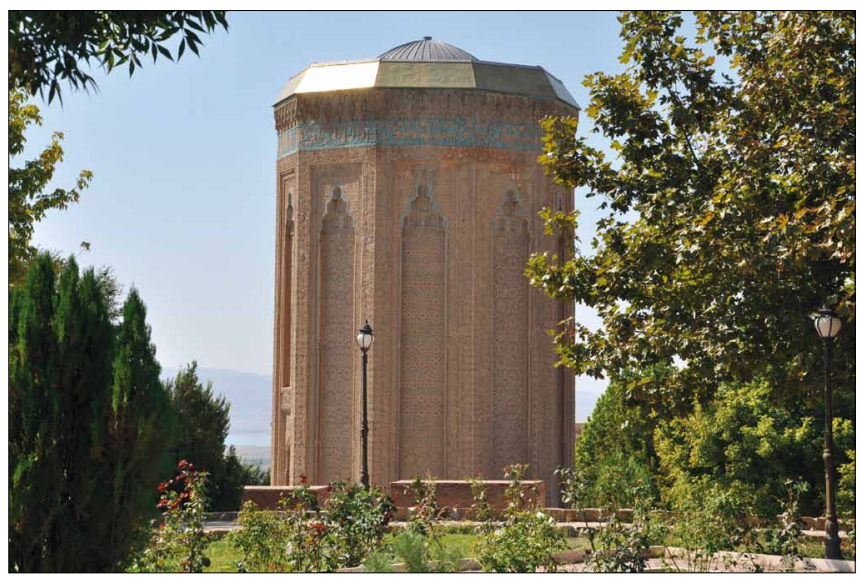

Obr. 4. Adžemi ibn Abubakr, zv. Nachčivání, Mausoleum Momine Chátún, Nachičevan, 1186 - 1187. Foto: David Majer, 2011.

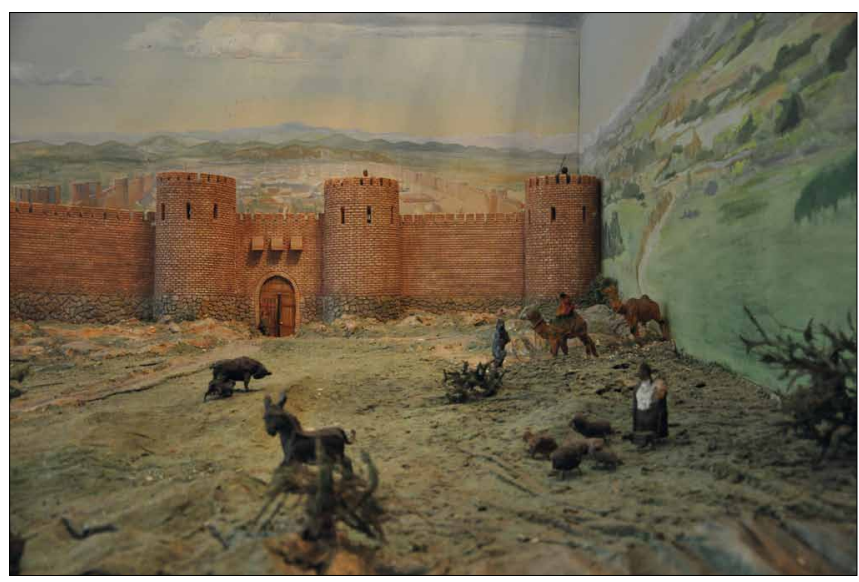

Obr. 6. Model starověké Gabály, Gabála, Muzeum historicko-regionálních studií. Foto: David Majer, 2011.

Ve druhé polovině 9. století v oblasti kolem Urmijského jezera vykrystalizovaly první obrysy Mannejského království. Asyrské a urartské prameny počátku 1. tisíciletí př̀. n. l. hovoří o hustém osídlení a „královských městech“ $s$ vyvinutými znaky raného urbanismu. Archeologická bádání dospěla k objevům řady dobře opevněných sídel s centrální pevností (citadelou) a složitým systémem vnitřního uspořádání. Takovým opevněným městem bylo např. Hasanlutepe na jižním břehu Urmijského jezera, které je možno zařadit do období mezi lety 1000 a 800 př̀ n. l. Tato opevněná města, zmiňovaná $\mathrm{v}$ klínopisných pramenech, ${ }^{6}$ byla bezpochyby nejen centry tehdejších „státư", ale i tranzitními zastávkami, poprípadě křižovatkami dálkových cest.

Jedním z nejdůležitějších obchodních středisek a průsečíkem dálkových cest $\mathrm{v}$ oblasti se ještě $\mathrm{v}$ období Asyrské ríše stal Tabríz. Pokud ovšem platí prèedpoklad, že lze toto pozdější centrum íránského Ázerbájdžánu identifikovat s pevností

6 Alijev 2012, 47-48. 


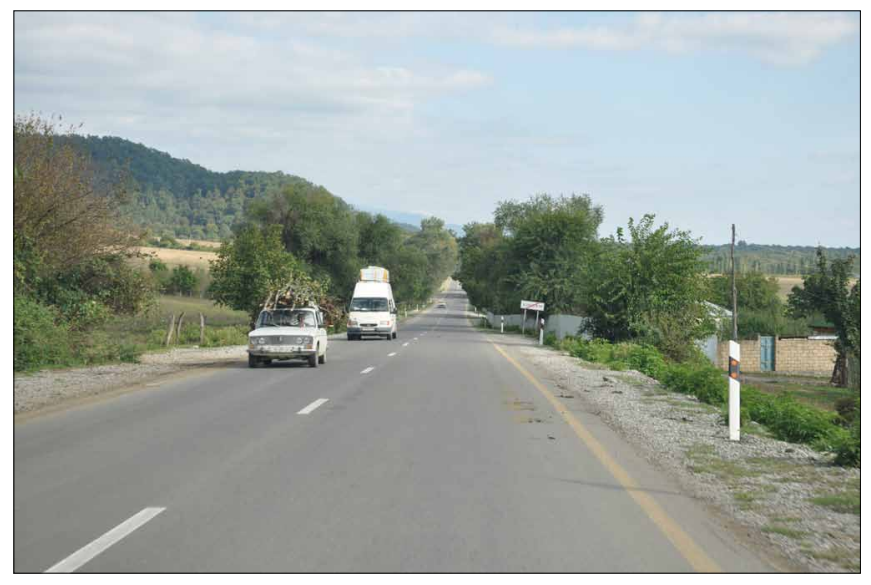

Obr. 7. Silnice z Gabály do Ismayilli přesně kopírující průběh Severoázerbájdžánské (albánské) větve Hedvábné cesty. Foto: David Majer, 2012

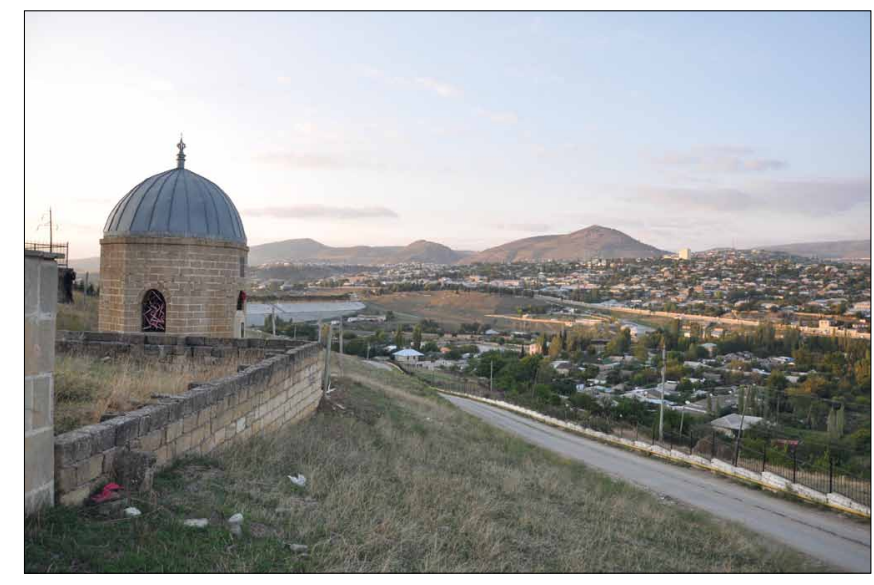

Obr. 8. Šamachy, celkový pohled z vrchu Yeddigümbez (Sedm kupolí). Foto: David Majer, 2011.

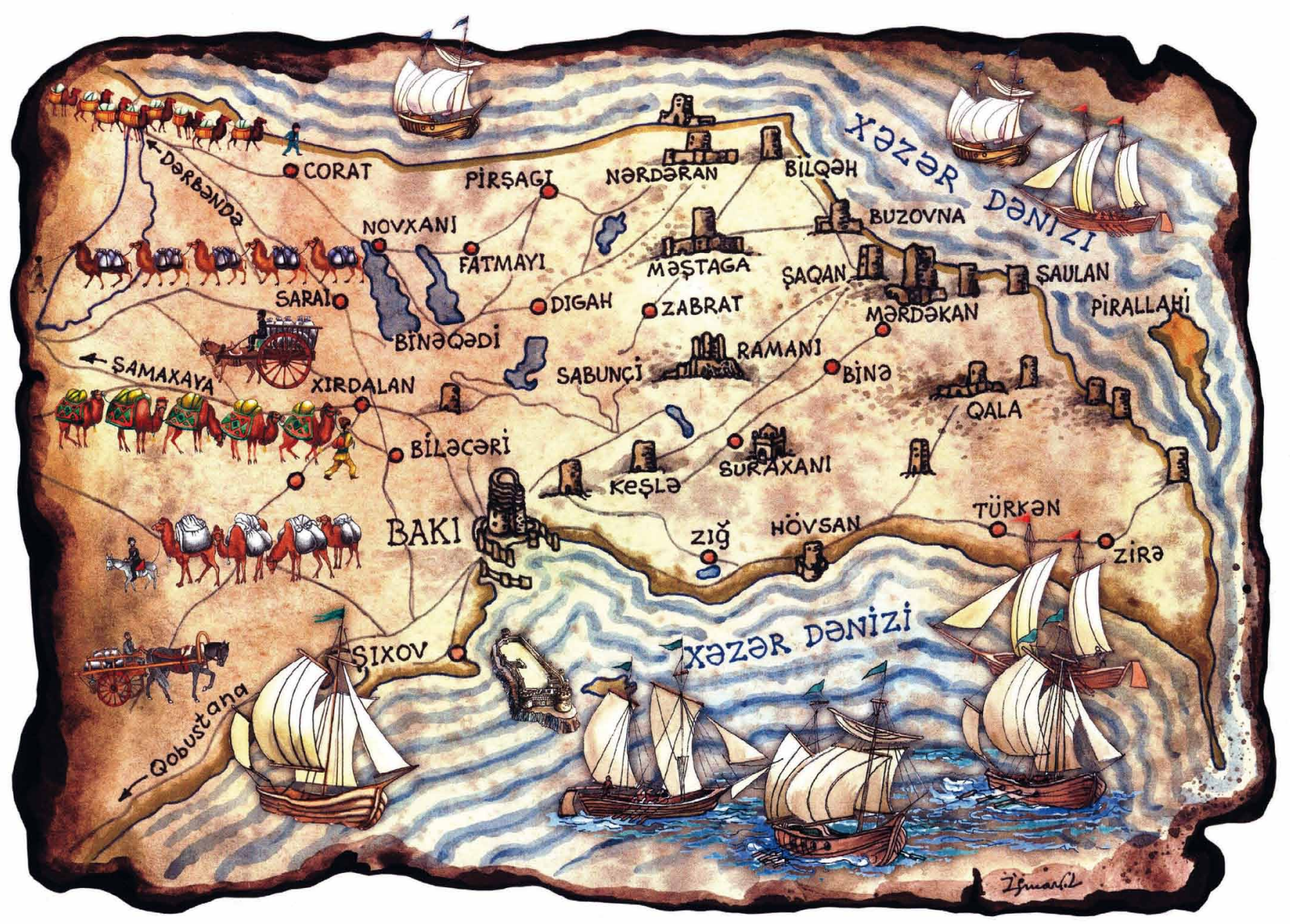

Obr. 9. Ismayil Asad oglu Mammadov, Kreslená mapa středověkých pevností na Apšeronském poloostrově, 2004. Foto @ David Majer. 


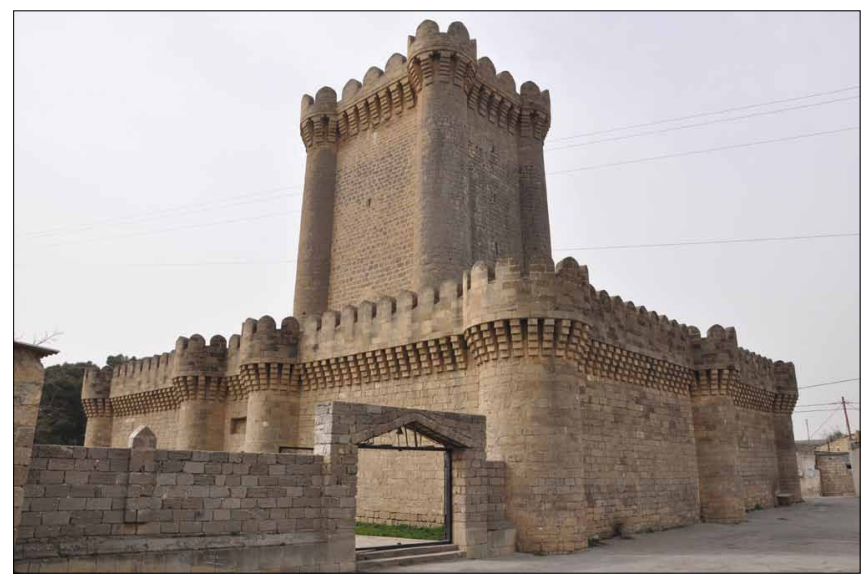

Obr. 10. Mardakan, opevněná strážní věž, 1232. Foto: David Majer, 2011.

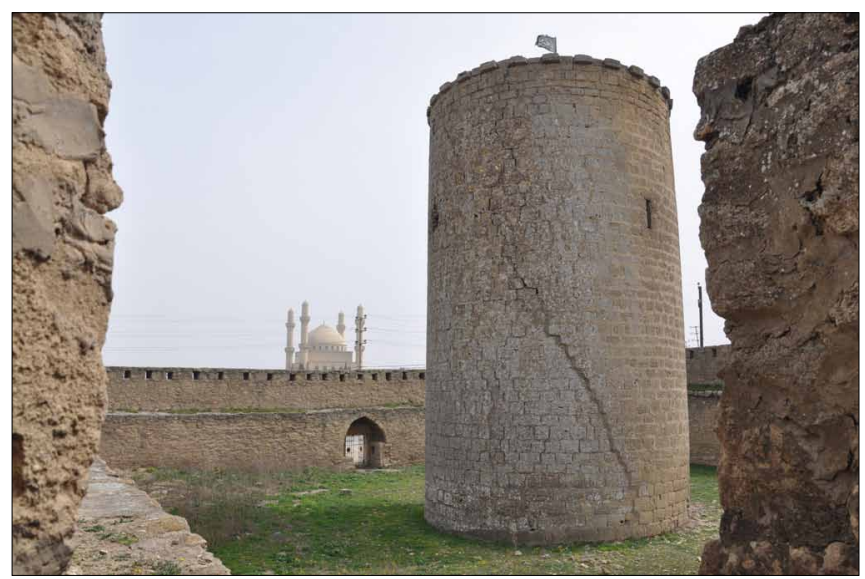

Obr. 12. Nardaran, opevněná strážní věž, 14. století. Foto: David Majer, 2011.

Tauri, zmiňovanou v asyrském nápisu z roku 714 př. n. l. (dnes ve sbírkách pařížského Louvru), popisujícím historii vlády krále Sargona II. ${ }^{7}$

Z Trapezuntu (pozdějšího Trabzonu) na černomořském pobřeží vedly již $\mathrm{v}$ tomto období $\mathrm{v}$ podstatě dvě paralelní cesty $\mathrm{k}$ údolí Araxu. Jedna z nich kopírovala část trasy, kterou popsal ve své Anabazi Xenofón ${ }^{8}$ a procházela údolím řeky Çoruh (možná Xenofóntův Harpasos?). Druhá z cest vedla až k údolí horního toku Západního Eufratu (druhá varianta pro Xenofóntův Harpasos? $)^{9}$ a přes dnešní Erzurum př́mo $\mathrm{k}$ hornímu Araxu. Zde se nachází několik strategických tranzitních zastávek a center tehdejšího obchodu. Jedná se v prvé řadě o Nachičevan, jedno $\mathrm{z}$ nejstarších měst $\mathrm{v}$ celé oblasti a důležitý brod přes Arax, déle o Džulfu nebo Ordubad.

O tom, že dálkové cesty tímto regionem probíhaly kontinuálně, svědčí i řada dochovaných středověkých památek. Na-

7 K tomu více: Fuchs 1994; Mayer 1983, 65-132.

8 Xenofón 1974, 140.

9 Ibidem, 258.

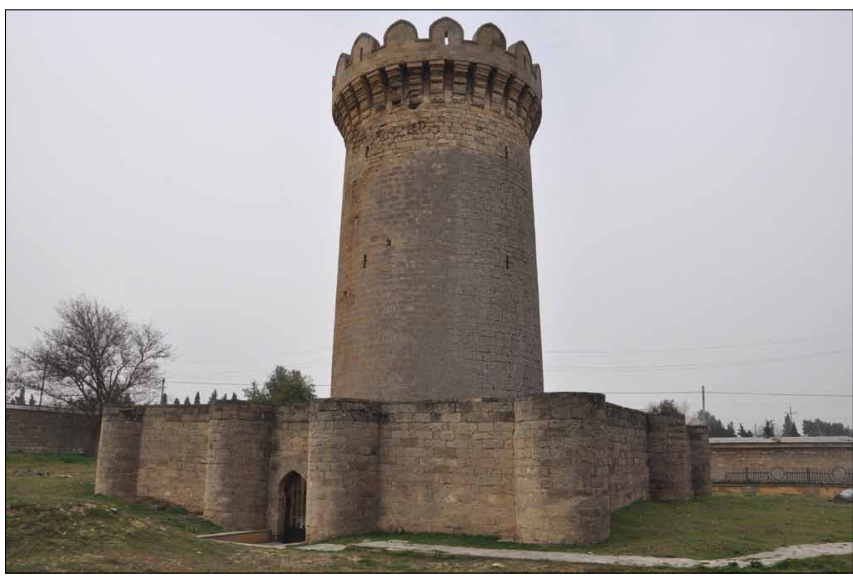

Obr. 11. Mardakan, opevněná strážní věž, 1301. Foto: David Majer, 2011.

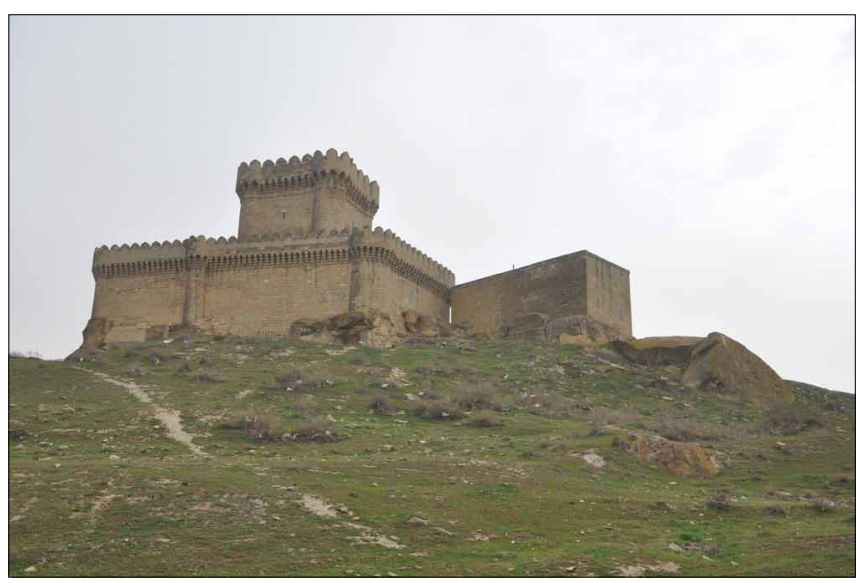

Obr. 13. Ramany, vrch s opevněnou strážní věží a mešitou, 13. století. Foto: David Majer, 2011.

př́klad karavanseráj v Džamaldinu (12. století), ${ }^{10}$ karavanseráj Charaba poblíž osady Chok (14. století), ${ }^{11}$ několik hradů a strážních věží a také unikátní lokalita, kde se nachází oba Chudaferinské mosty. Starší z nich pochází ze 7. a mladší z 12. století. $^{12}$

Odtud cesta směřovala dále ke zmíněnému Tabrízu, kde se napojovala na hlavní tepnu Hedvábné cesty. Průběh této komunikace vedoucí z oblasti jižního Černomoří a ve své střední části procházející údolím Araxu, lze bez velkých komplikací poměrně přesně rekonstruovat na většině míst i $\mathrm{v}$ terénu. Do určité míry je průběh této důležité cesty zmíněn i v písemných pramenech. O jejích jednotlivých částech hovoří nejen Hérodotos, Xenofón či Strabón, ale mnohem podrobněji také středověcí cestovatelé Marco Polo, Odorik z Pordenone, Vilém z Rubruku, později např. Afanasij Nikitin, Adam Olearius a další.

10 Talibov 2008, 51.

11 Ibidem, 190; Naxçıvan memarliq mektebi 2005, 15-22.

12 Giyasi 2010, 30-34. 


\section{SEVEROÁZERBÁJDŽÁNSKÁ (ALBÁNSKÂ) VĚTEV HEDVÁBNÉ CESTY}

Pravděpodobně o něco mladší, pokud jde o pravidelnou frekvenci obchodních kontaktů, je druhá východo-západní komunikace, vedoucí severněji, podél jižního podhůří Velkého Kavkazu. Značná část její trasy prochází údolím řeky Kury, počínaje na východě oblastí kolem města Mingečevir ${ }^{13}$ a konče zhruba v okolí pozdějšího města Chašuri v Gruzii. Severoázerbájdžánská větev Hedvábné cesty vedla přibližně v linii: (Apšeron, Baku) - Šamachy - Ismayilli (odtud pokračovala jiná větev do Staré Gabály, dále na severozápad k Šeki a ke kavkazským průsmykům) - Gandža - Červený most Tbilisi - černomořské pobřeží. Tato větev je dodnes charakteristická četnými odbočkami vedoucími do malebných horských osad a vesnic (jako např. Basgal či Lahič), která jsou dodnes důležitými centry umělecko-řemeslné výroby. ${ }^{14}$

Obecně platí, že místa ležící na této ázerbájdžánské větvi Hedvábné cesty byla od starověku známá jako střediska obchodu, řemesel a svébytné kultury. Jsou zmiňována řadou antických, středověkých i novověkých cestovatelů, misionářů, geografů, kupců, poutníků i spisovatelů, mezi nimiž nechybí Plinius starší, Ptolemaios, Giosafat Barbaro, Anthony Jenkinson, Evlija Čelebi, nebo již zmínění Hérodotos, Strabón, Marco Polo, Vilém z Rubruku, Odorik z Pordenone, Afanasij Nikitin a další. ${ }^{15}$ Je proto nutno zastavit se krátce alespoň u dvou politických, obchodních a kulturních center, jimiž tato cesta procházela.

Rozvaliny Gabály (Čuchur Gabály neboli Staré Gabály) jsou památkou na město, jehož historie je dlouhá téměř dva a půl tisíce let. Gabála byla od 3. století n. l. hlavním městem Albánského království. Hovoří o ní řada starověkých autorů. Plinius starší (1. století n. 1.) ji nazývá Cabalakou, Ptolemaios (2. století n. 1.) zase Chabalou. Gabála byla v posledních staletích před naším letopočtem a v prvních staletích našeho letopočtu známá jako důležité politické, kulturní a náboženské centrum celého Kavkazu. Město mělo silné obranné hradby a také jeho městská zástavba odpovídala jeho významu. Dủležitost města, s paláci a domy patřícími aristokracii, s bazary a tržišti, řemeslnickými čtvrtěmi a mincovnami, potvrzuje několik středověkých ázerbájdžánských, gruzínských, arabských a perských písemných pramenů. Město bylo rovněž rezidencí hlavy Albánské apoštolské autokefální církve. Od 7. století byla Gabála součástí různých států a v 18. století se stala znovu hlavním městem, tentokrát ovšem Gabálského sultanátu. Novodobé dějiny města se ovšem týkají již odlišné lokality, vzdálené od Staré Gabály několik kilometrů. ${ }^{16}$

Jiným městem, jehož význam přesahuje lokální rámec, je důležitá tranzitní zastávka a křižovatka dálkových cest ve-

13 Alijev - Gadirov 1985, 37-45.

14 Ibidem.

15 Guseynov 2009.

16 Ibidem, $19-20$.

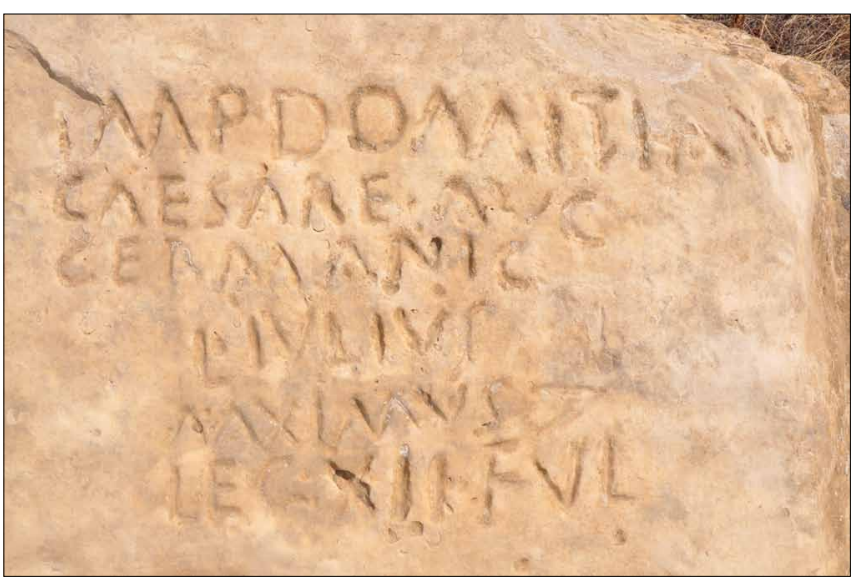

Obr. 14. Ř́mský nápis vytesaný v Gobustanu mezi lety 84 a 96 jako památka na pobyt skupiny vojsk, náležejících $\mathrm{k}$ Legii XII Fulminata a vedených centurionem Luciem Juliem Maximem. Foto: David Majer, 2012.

doucích z mnoha směrů, centrum středověkého obchodu Šamachy. Město rozvíjelo obchodní a kulturní vztahy se zeměmi Orientu a Západu již od starověku. Jeho jméno ve tvaru Samacheia, respektive Kemacheia jako první ve svém díle zmínil Ptolemaios. Město se od té doby v písemných, později i ikonografických a kartografických pramenech objevuje pravidelně. V roce 1375 například pod názvem Xamay také v tzv. Katalánském atlasu. ${ }^{17}$ Všechny zmínky napříč staletími svědčí o kontinualitě jeho nadregionálního významu. Není proto divu, že ještě v 16. století anglický kupec a diplomat Anthony Jenkinson nazval Šamachy "nádherným královským městem". 18

Od 6. století bylo Šamachy hlavním městem státu Šírván. ${ }^{19}$ Nové hradby města byly postaveny v 11. století a části těchto obranných zdí se zachovaly dodnes. Vybavenost středověkého města byla popsána jedním z jeho rodáků, velkým básníkem a myslitelem 12. století Chákáním Šírváním, jenž ve svém díle srovnává Šamachy s Bucharou, když tvrdí, že: „velikost šamachinské země snese srovnání s velkolepostí Buchary“. ${ }^{20}$

Šamachy bylo jedním z největších obchodních center Kavkazu a jeho nejcennějším zbožím bylo hedvábí, koberce a kobercové výrobky. ${ }^{21}$ Šírvánské hedvábí bylo ve velkém vyváženo do zahraničí, zejména do Itálie a Francie, již ve 13. století. Ruy González de Clavijo, v letech 1403-1405 vyslanec Jindřicha III. Kastilského ke dvoru Tamerlánovu, psal v 15. století o obchodu s hedvábím v Šamachy, podle jeho názoru atraktivním i pro kupce $\mathrm{z}$ Janova a Benátek. ${ }^{22}$ Ambrosio Contarini, benátský diplomat, navštívil Šamachy rovněž v 15. století a také on

\footnotetext{
17 Ibidem, 22-27.

18 Salimova 2003, 248-265; Dženkinson (online).

19 Alijev 1995, 211.

20 Širvani 1959; Guseynov 2009, 22.

21 Tagijeva 2012, 12-14 a 64-67.

22 Řada svědectví in: Klavicho 1990.
} 




Obr. 15. Přibližný průběh ázerbájdžánských větví Velké hedvábné cesty. Autor: David Majer, 2013. Mapový podklad: Mapa světa 1:2 500 000, č. 55 (Tbilisi), Moskva 1976, Ústřední archiv zeměměřictví a katastru v Praze.

vyzdvihl vysokou kvalitu místního hedvábí. ${ }^{23}$ Cestovatel Johann Schiltberger napsal, že "nejlepší hedvábí pochází z Šamachy" a používá se pro výrobu sametu. ${ }^{24}$

Podle arabských autorů bylo město součástí hlavních východo-západních obchodních tras již v 9.-10. století. V blízkosti Šamachy se nachází zř́iceniny dvou známých a téměř nedostupných pevností Gulistan a Galei Bugurd, vybudovaných $\mathrm{z}$ důvodu ochrany komunikací, které se ve městě spojovaly či naopak větvily. ${ }^{25}$

\section{SEVERO-JIŽNÍ (DERBENTSKO-BAKUSKÁ) VĚTEV HEDVÁBNÉ CESTY}

Vzhledem $\mathrm{k}$ intenzitě dopravní frekvence pravděpodobně nejmladší ze tří hlavních cest, které procházely územím historického Ázerbájdžánu, je severo-jižní větev Hedvábné ces-

23 Tagijeva 2012, 12-14.

24 Schlemmer 1983.

25 Pourshariati 2008, 278-281. ty, vedoucí podél západního pobřeží Kaspického moře. Tato cesta zůstává dodnes hmatatelným symbolem kontaktů mezi dvěma odlišnými světy Evropy a Orientu. Cesta překračovala či obcházela $\mathrm{z}$ dopravního hlediska velmi obtížné terény Velkého Kavkazu. Ideálním místem pro přechod z Povolží do Kuro-araxské nížiny a dále do nitra Střední Asie byla Kaspická brána (Porta caspica), zvaná též Železná nebo Alexandrova, nacházející se v srdci pozdějšího Derbentu.

Toto místo bylo přirozeným a nejsnazším průchodem podél Kaspického moře v severo-jižním směru. Jeho důležitost a strategický význam byly př́ícinou úsilí Skytů, Sarmatů, Alanů, Hunů, Chazarů a dalších kmenových svazů či etnik o kontrolu nad tímto územím. Odvěké různice v této oblasti nebyly ničím výjimečným. Po přelomu letopočtu prrispěla $\mathrm{k}$ napětí v oblasti zejména doba stěhování národů, později příchod turkických kmenů, $\mathrm{v}$ raném středověku vznik jihoruských knížectví (viz např́ílad závěr legendárního Svjatoslavova tažení v roce $965^{26}$ ), pronikání vikingů do Střední Asie, vznik Zlaté hordy, nájezdy Mongolů a Tamerlánových vojsk, o politických, hospodárských, náboženských a etnických změnách

26 Gumiljov 1971, 161. 
v dějinách samotné Persie nemluvě. Tento konflikt světů, dá-li se to tak nazvat, přetrvával de facto až do nedávné minulosti, přičemž v posledním tisíciletí se odehrával převážně ve znamení sousedství ruského a íránského živlu, jehož dědictvím je do určité míry i současnost tohoto regionu.

$\mathrm{V}$ období vrcholného středověku se začal poprvé výrazněji projevovat strategický tranzitní význam opevněného př́stavního města Baku. Osídlení této části Apšeronského poloostrova i dějiny samotného Baku jsou samozřejmě mnohem starší, než je vznik středověkého pevnostního města s několika velkými karavanseráji. ${ }^{27}$ Místo př̀ Bakuském zálivu bylo totiž odnepaměti nedílnou součástí sítě pevností, strážících severo-jižní průchod směrem z Derbentu a Šamachy na jih i pobřeží Kaspického moře.

Doposud ne zcela vysvětleno zůstává rozmístění a velký počet stř̌edověkých pevností, rozprostřených na Apšeronském poloostrově, včetně místa zvaného Gala (Qala). Přesto, že v rámci tohoto př́spěvku nelze tomuto tématu věnovat dostatek prostoru, je nutno položit alespoň dvě, prozatím uspokojivě nezodpovězené otázky. Otázka první zní, co, proč a před kým tato místa apšeronské pevnosti chránily? Otázka druhá zní, $\mathrm{z}$ čeho zde lidé žili? Oblast je totiž zcela bez vody, respektive nachází se zde pouze voda nezdravá, panuje zde drsné klima, silný vítr, krajina je a v historické době vždy byla takřka bez vegetace. Přesto archeologická situace napřr. již zmíněného sídliště Gala svědčí o tom, že šlo o křižovatku obchodních cest. Cesty však podle dochovaných stop, objevených $\mathrm{v}$ průběhu nedávných výzkumů, vedou odnikud nikam.

Cesty ze severu se jižně od Apšeronského poloostrova spojovaly před přechodem Kury, přičemž poslední možností, jak ji snáze překročit před tím, než se řeka rozlije na svém dolním toku, představoval brod v blízkosti dnešního města Saljanu, snad v okolí Kumlevarského mostu, postaveného však až v 16. století.

V této oblasti se nachází rovněž výjimečná lokalita známá pod názvem Gobustan. Jedná se o přirozenou tranzitní zastávku využívanou od pravěku. Oblast je kontinuálně osídlená přibližně 10000 let a strategický význam neztratila ani v mladších obdobích. Toto území je nutno vnímat rovněž ve smyslu prímého vlivu starověké Rímské říše. $Z$ ohromného počtu úchvatných památek minulosti Ázerbájdžánu vyčnívá fascinující rímský nápis, který zde mezi lety 84 a 96 n. l. nechal vytvořit jako památku na římskou př́tomnost na tomto území Lucius Iulius Maximus, centurion Legie XII Fulminata. ${ }^{28}$ Tato významná památka pozdního starověku není v Ázerbájdžánu osamocena. Z plejády historických sekundantů gobustanského nápisu je nutno vyzdvihnout alespoň tajemnou skálu se středověkou pevností v Ramany na Apšeronském poloostrově. Jedná se pravděpodobně o nejvzdálenější stopy pobytu "Románư“ (tj. Římanů, přesněji řečeno římských legií) na východ od hranic impéria.

\section{PRAMENY A LITERATURA}

Alijev, I. G. - Gadirov, F. V. (1985): Gabala. Baku, 37-45.

Alijev, Igrar (1995): Istoriâ Azerbajdžana s drevnejših vremen do načala XX veka. Baku, 211.

Alijev, Igrar, ed. (2012): Přehled dějin Ázerbájdžánu. Ostrava: Ostravské muzeum, 47-48.

Dženkinson, Entoni: Putešestvie Antona Dženkinsona v Persiû. (online). (http://www.vostlit.info/Texts/rus11/Jenkinson/text3.phtml?id=415).

Fuchs, Andreas (1994): Die Inschriften Sargons II. aus Khorsabad. Göttingen.

Giyasi, Jafar (2010): Bridges of Khudaferin. Irs Heritage, 2, 30-34.

Gumiljov, Lev Nikolajevič (1971): Objevení země Chazarů. Praha.

Guseynov, Rauf (2009): The Great Silk Road and Azerbaijan. Baku.

Klavicho, Rui Gonsales de (1990): Dnevnik putešestviâ v Samarkand ko dvoru Timura (1403-1406). Moskva.

Kvaçidze, Viktor (2009): Xezer Atlantidasi. Baki.

Luckenbill, Daniel David (1926): Ancient Records of Assyria and Babylonia. Chicago, 213.

Mayer, Walter (1983): Sargons Feldzug gegen Urartu - 714 v. Chr. Mitteilungen der Deutschen Orient-Gesellschaft, 115, 65-132.

Naxçuvan memarliq mektebi (2005). Naxçıvan.

Nováček, Karel et al. (2008): Research of the Arbil Citadel, Iraqi Kurdistan, First Season. Památky archeologické, XCIX, 259-302.

Pourshariati, Parvaneh (2008): Decline and Fall of the Sasanian Empire. The Sasanian-Parthian Confederacy and the Arab Conquest of Iran. New York, 278-281.

Salimova, A. T. (2003): Velikij Šelkovyj Put' i Azerbajdžan. Böyük Ipek Yolu. Baku, s. 248-265.

Schlemmer, Ulrich, red. (1983): Johannes Schiltberger. Als Sklave im Osmanischen Reich und bei den Tataren: 1394-1427. Stuttgart.

Scrinzi, Luigi (2011): Signature of the Centurion. Irs Heritage, 4, 10-13.

Širvani, Hagani, (1959): Izbrannye proizvedeniâ. Baku.

Tagijeva, Roja, (2012): Tradition of the Azerbaijani Carpet. Země věčného ohně II. Ostrava: Ostravské muzeum, 12-14 a 64-67.

Talibov, Vasif et al. (2008): Naxçıvan abideleri ensiklopediyası. Naxçıvan. Xenofón (1974): Anabaze. Praha.

\section{AUTOR}

David Majer (nar. 4. 5. 1974), vystudoval obor teorie a dějiny výtvarných umění na Filozofické fakultě Univerzity Palackého v Olomouci. Odborný pracovník Ostravského muzea. Autor koncepce a zakladatel Muzea Jantarové stezky a Hedvábné cesty v Ostravě (od roku 2018). Ředitel Ázerbájdžánského a kaspického kulturního fóra (od roku 2011). Odborně se specializuje na dějiny a kulturu Střední Asie a Blízkého východu - fenomén Hedvábné cesty. Autor mnoha mezinárodních výstav a expozic, např. doposud nejvelkolepějši přehlídky ázerbájdžánské historie a kultury ve Střední Evropě s názvem Země věčného ohně. Poklady největších ázerbájdžánských muzeí poprvé ve Strední Evropě, realizované v Ostravském muzeu v letech 2012 a 2013.

Kontakt: PhDr. David Majer, Ostravské muzeum, př́spěvková organizace, Masarykovo nám. 1, 72841 Ostrava

e-mail: david.majer@seznam.cz

27 Kvaçidze 2009.

28 Scrinzi 2011, 10-13. 